\title{
A review of the scorpion fauna of Saudi Arabia
}

\section{Abdulrahman Khazim Al-Asmari ${ }^{1^{*}}$, Abdulaziz Abdalla Al-Saif ${ }^{2}$, Nasreddien Mohammed Abdo ${ }^{1}$, Khalaf Radan Al-Moutaery ${ }^{3}$ \& Naif Obeid Al-Harbi ${ }^{4}$}

${ }^{1}$ Research Center, Armed Forces Hospital, Riyadh, Saudi Arabia

2 Department of Medicine, Armed Forces Hospital, Riyadh, Saudi Arabia

${ }^{3}$ Neurosurgery Department, Armed Forces Hospital, Riyadh, Saudi Arabia

${ }^{4}$ Pharmacy Department, College of Health Sciences, King Saud University, Riyadh, Saudi Arabia

\section{ABSTRACT}

The scorpions of Saudi Arabia were surveyed in the major regions of Jazan, Al-Medina, Al-Baha, Hail, and Riyadh, in addition to nine provinces surveyed more superficially. Jazan $(1,440$ specimens) had 10 buthids and two scorpionid species and subspecies; Al-Medina (867) had seven buthid and two scorpionid species and subspecies, one of which, the scorpionid Scorpio maurus (palmatus?), needs further confirmation of identity. The Al-Baha region (2421 specimens) contained five buthids and two scorpionid species and subspecies; Hail $(1,921)$ had eight buthid and two scorpionid species and subspecies - the most common subspecies here was Scorpio maurus kruglovi. Androctonus crassicauda and Leiurus quinquestriatus were only found in Hail and Al-Baha; Androctonus bicolor was newly recorded in Hail and Riyadh. Riyadh (4,164 specimens) had nine buthid, one scorpionid and at least two hemiscorpiid species and subspecies. The Saudi fauna was found to comprise at least 28 species and subspecies of the families Buthidae, Scorpionidae and Hemiscorpiidae.

Keywords: Buthidae, Scorpionidae, Diplocentridae

\section{INTRODUCTION}

Arachnologists have been puzzling over the relationships of arachnids for over a century and for an appreciable time the problem seemed no closer to a satisfactory resolution (Shultz 1990). Some have speculated that arachnids are a polyphyletic grade of terrestrial chelicerate (Savory 1971, Krauss 1976, Manton 1977, Van der Hammen 1977a). Weygoldt \& Paulus (1979a), whose works were based on information derived from an extensive review of chelicerate biology, were the first to apply cladistic reasoning to the arachnid problem and they discovered the evidence that arachnids are monophyletic. Van der Hammen (1977a), who was the most prolific of the workers in this field (Weygoldt \& Paulus 1979b, Van der Hammen 1977b, 1979, 1969, 1982, 1985a, 1985b) has rejected cladistics as too rigid and atomistic to offer a solution for the problems of arachnid evolution, and (1986a) suggested that "discovery of unexpressed potentialities" holds the key to understanding macroevolutionary change. The conclusions of Van der Hammen went unchallenged apart from Lindquist (1986b), but Shultz (1990) admitted that arachnids are probably monophyletic.

The phylogenetic position of scorpions was in dispute but the order limits were clear (Shultz 1990). Weygoldt \& Paula (1979a) thought that fossil scorpions were more closely related to Eurypterida than to recent scorpions, but the more recent works of KjellesvigWaering (1989) have proved this inappropriate, based on the pectinal presence in fossil scorpions, in addition to the stomotheca, transverse carapacial furrow and biocondylar femoropatellar joints. Recent scorpions have major differences from other arachnids, such as the flagellar spermatozoa, opisthosomal venom glands, etc. (Van der Hammen 1985c, Shultz 1990).

Detailed recent information about scorpions is available in scorpiological websites (Arachnodata 2009a, 2009b; Euscorpius 2009, ITG Library 2009, WRBU 2009, The scorpion fauna 2009). A lot of controversy has accumulated recently on scorpion taxonomy, especially in higher level systematics and in relation to other arthropods (Fet \& 
Bechly 2000, Fet \& Braunwalder 2000). Nine families were established by the end of the $20^{\text {th }}$ century (Stockwell 1989, 1992; Sissom 1990, Gromov 1998, Prendini 2000), and at least sixteen were recognised a decade later (Prendini 2000, Fet et al. 2000, 2005; Prendini 2001, 2003a, 2003b; Soleglad \& Sissom 2001), partly by abolishing some (e.g. Diplocentridae) and re-instating others (Prendini \& Wheeler 2005), based on particular morphological features (Polis 1990, ITG Library 2009, Rosin 1965, 1969a, 1969b, 1973; Lourenco 1985). The family Hemiscorpiidae was established, abolished and finally reinstated (The Scorpion Files 2009, following Fet \& Soleglad 2005).

As regards the scorpions of Saudi Arabia, earlier reports by several investigators (including Vachon 1979, and more recently Al-Hajjaj 2005, Al-Sadoon \& Al-Farraj 2008) indicate the presence of only two medically important species (Androctonus crassicauda and Leiurus quinquestriatus: both Buthidae) in the Riyadh region. Other buthid species such as Buthacus leptochelys and Vachoniolus (Buthacus) minipectinibus were not reported from this region, but were reported to be extant in other regions (Vachon 1979). Buthidae is the largest of the scorpion families (Fet and Lowe 2000, Polis 1990) spreading over many regions, and widespread in the Old World, especially in Asia and Tropical Africa. The recent and continuing studies of Hendrixson $(2002,2006,2008)$ and El-Hennawy (2009) on scorpions of the Arabian Peninsula were helpful and useful guides in our work.

Medically important species have been reported in the older literature (Al-Asmari et al. 2007, 2009a, 2009b), but species that are allegedly unimportant medically turn out to produce medically serious outcomes in Saudi Arabia, such as intracranial bleeding and other complications (Annobil 1993, Annobil et al. 1991) and other works and information from personal contacts report the same for other species (e.g. Compsobuthus werneri, Apistobuthus pterygocercus, Scorpio maurus kruglovi, Scorpio maurus (palmatus?) and Hemiscorpius spp.).

\section{MATERIALS \& METHODS}

The bases of scorpion classification have changed in recent years. The important methods and keys of Vachon (1979) and Sissom (1990) were based on three trichobothrial patterns and other morphological features referring to their distribution and dimensions on the body (Figs. 1 \& 2). Preliminary work done in the Arabian Peninsula and Saudi Arabia in particular were based on these keys (Al-Asmari et al. 2007, 2009a). Recent changes to higher classification were adopted by The Scorpion Files (2009), following Fet \& Soleglad (2005), but recent work in the Arabian Peninsula used the work of Hendrixson $(2002,2006,2008)$. Here we adopt the higher classification of The Scorpion Files (2009):

Infraorder: Orthosterni Pocock, 1911 (extant scorpions)

Parvorder: Buthida Soleglad et Fet, 2003

Superfamily: Buthoidea C. L. Koch, 1837

Family: Buthidae C. L. Koch, 1837 (thick-tailed scorpions)

Parvorder: Iurida Soleglad et Fet, 2003

Superfamily: Scorpionoidea Latreille, 1802

Family: Scorpionidae Latreille, 1802 (burrowing scorpions or pale-legged scorpions)

Subfamily: Diplocentrinae Karsch, 1880

Tribe: Nebini Kraepelin, 1905

Subfamily: Scorpioninae Latreille, 1802

Family: Hemiscorpiidae Pocock, 1893 (= Ischnuridae, =Liochelidae)

(Rock scorpions, creeping scorpions, or tree scorpions)

Subfamily: Hemiscorpiinae Pocock, 1893 


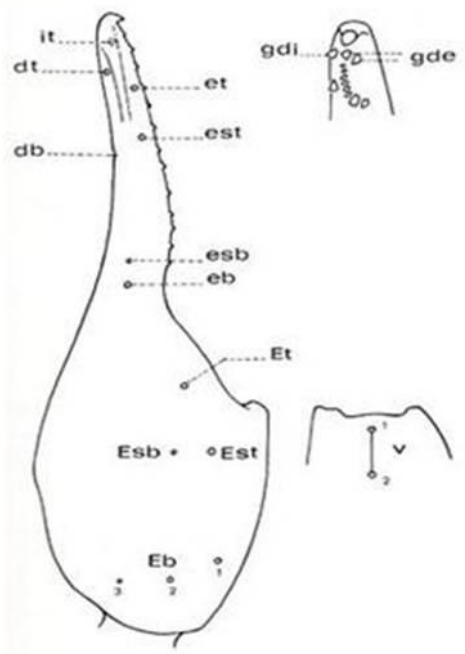

Figure 1: Distinctive distribution and nomenclature of the trichobothria on the pedipalp chela of Parabuthus liosoma, from Vachon (1979).

$d$ : dorsal; $i$ : internal; $e$ : external; $b$ : basal; iag: inner accessory granule; oag: outer accessory granule; $s b$ : sub basal; m: medial; $v$ : ventral; st: subterminal; $t$ : terminal; $t d$ : terminal denticle.
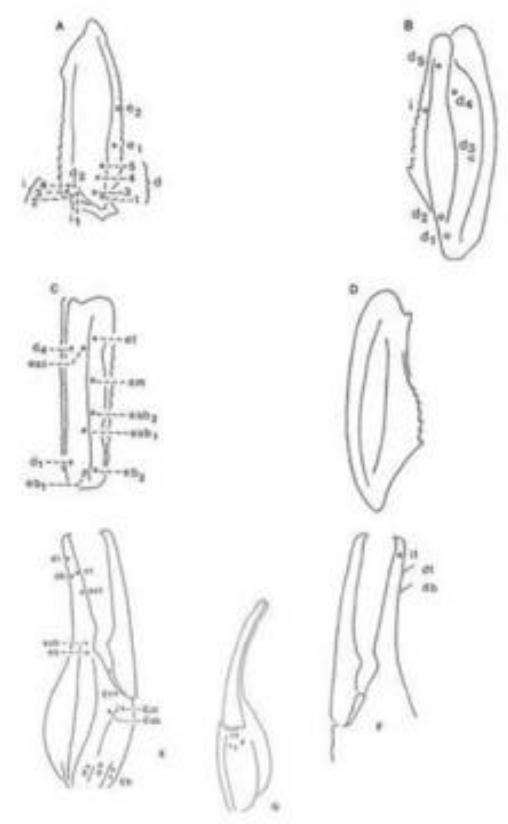

Figure 2: Dissected parts of the pedipalp showing type A basic trichobothrial pattern (from Sissom 1990). A: dorsal view of femur; B: dorsal view of patella; C: external view of patella; D: ventral view of patella; E: external view of chela; F: internal view of chela; $\mathrm{G}$ : ventral view of chela.

$d$ : dorsal; $i$ : internal; $e$ : external; b: basal; sb: sub basal; m: medial; v: ventral; st: subterminal; t: terminal.

\section{RESULTS \& DISCUSSION}

It was not our intention to keep scorpions in captivity, but this happened almost accidentally during the processes of unloading field batches, classifying and milking them (Al-Asmari et al. 2007, 2009a, 2009b). Some species were successfully reared to maturity, mated and their offspring reared (Al-Asmari et al. 2007, 2009a, 2009b), feeding them on the mealworms of previous methodologies (Lyon 1991, 1997). We have not confirmed scorpion parthenogenesis in Saudi Arabian populations, although this had been observed by some workers elsewhere (Lourenço 1994, 2008; Lourenço et al. 1996, 2000).

The total number of scorpions studied (Al-Asmari et al., 2007, 2009a, 2009b) in the five regions of Jazan, Al-Medina, Al-Baha, Hail and Riyadh (Figs. 3-5) was 10,813 specimens, in addition to other specimens reviewed from an extra nine localities. There were at least 28 species and subspecies recognized from these 14 locations, summarized in Table 1: they belong to three families - Buthidae, Hemiscorpiidae and Scorpionidae. 


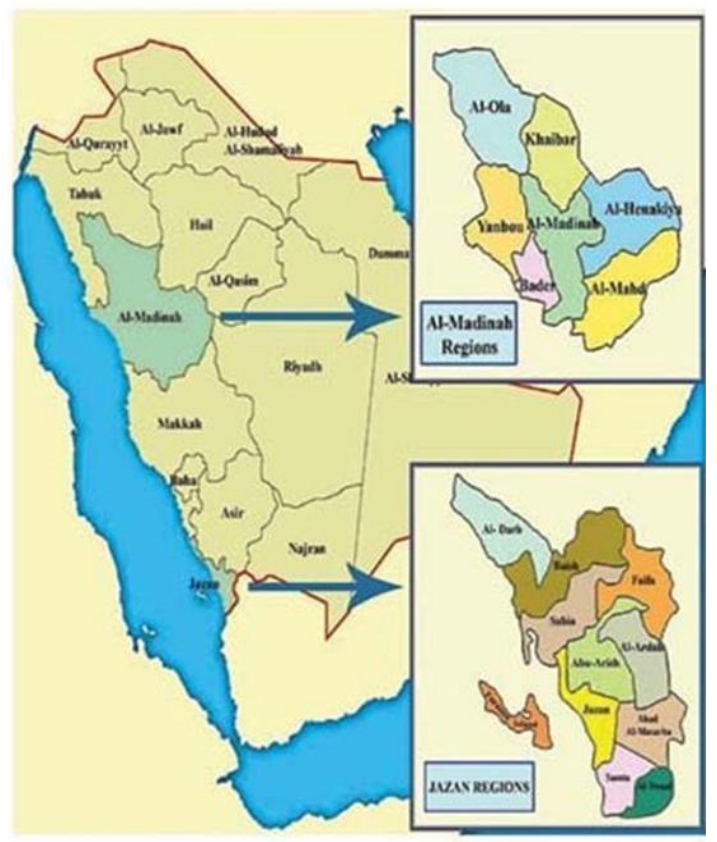

Figure 3: Map of Jazan and Al-Medina AlMunawwara regions, showing Jazan [Baish, Samtah, Abu Ariesh, Feifa, Bani Malik, Jazan City (Plantations), Sabia, Al-Khoba, Uhud Al-Masarha and Forasan Isles] and Al-Medina Al-Munawwara [Mahd Addahab, Tabouk Road, Yanbou Road, City (Medina) Road, City Center (Plantations), Uhud and Jedda Road].

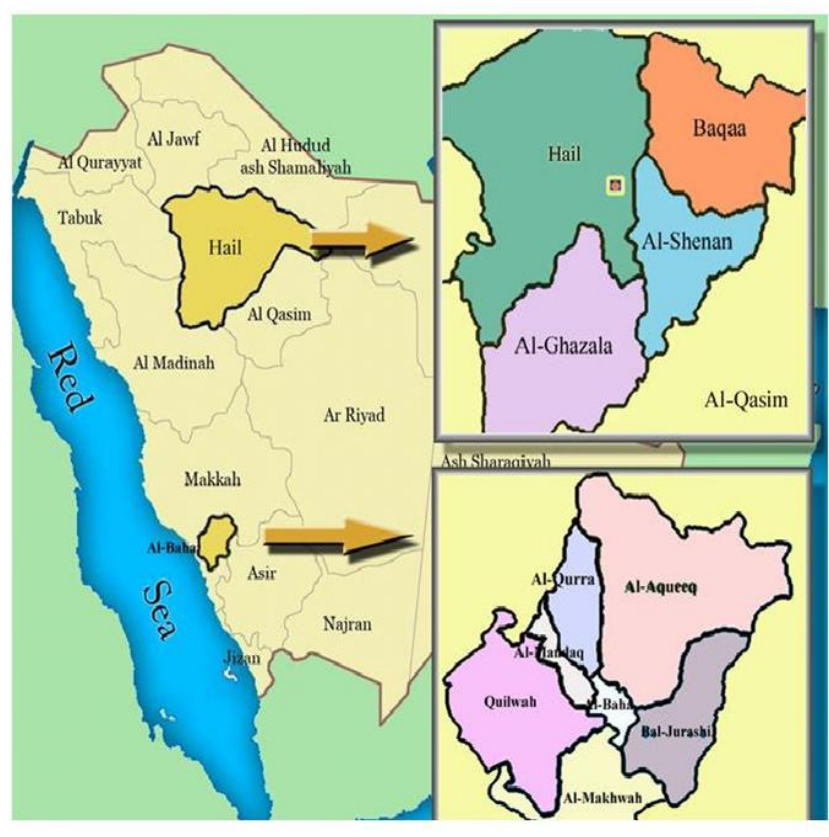

Figure 4: Map of Hail and Al-Baha regions, showing Al-Baha [Al-Quied, Al-Qura, Al-Mandag, Al-

Makhwaa, Galwaa, Al-Baha and Baljurashy cities]and Hail [Hail city, Baqaa, Al-Shenan and Al-Ghazala].

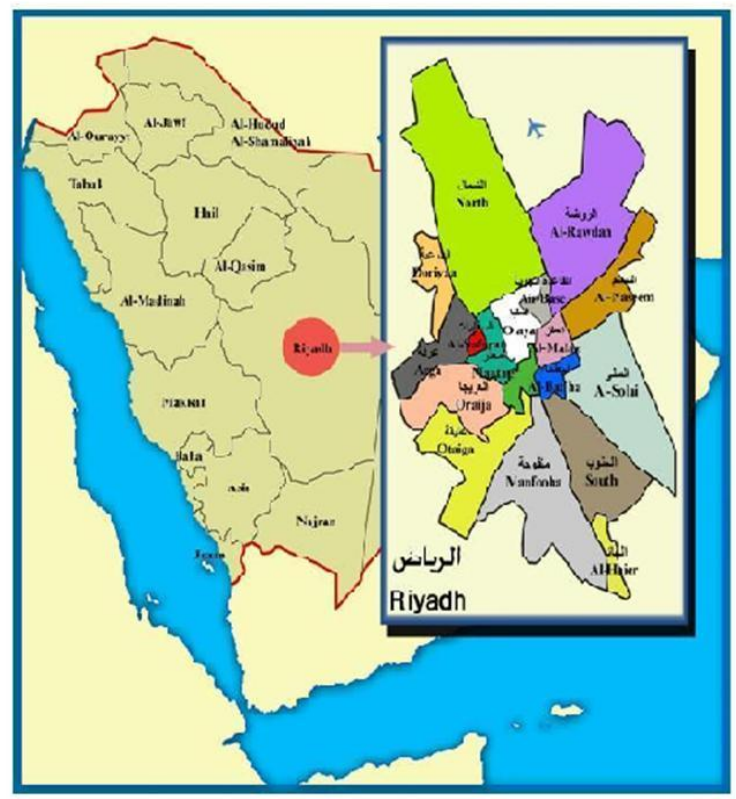

Figure 5: Map of Riyadh (Central) region, showing the sectors of Riyadh and locations of collections [Quasiem Road, Ramah road, Nazeem Road, Airport Road, Ben Ban, Dirab, Al-Ha'er, Al-Thumama, Janadria Road, Muzahimiya Road, Al-Kharj and Khashm Al-Aan]. 
Table 1. List of scorpion species and subspecies collected and identified in Saudi Arabia.

\begin{tabular}{|c|c|c|c|}
\hline & Species & Family & Region/Province \\
\hline 1 & Androctonus amoureuxi & Buthidae & Al-Gunfuda \\
\hline 2 & Androctonus australis & Buthidae & Al-Gunfuda, Aseer, Al-Medina \\
\hline 3 & Androctonus bicolor & Buthidae & $\begin{array}{l}\text { Aseer, Eastern R, Hail, Najran, Quassiem, Riyadh, } \\
\text { Tabuk }\end{array}$ \\
\hline 4 & Androctonus crassicauda & Buthidae & $\begin{array}{l}\text { Al-Gunfuda, Aseer, Eastern R, Hafr Al-Batin, Hail, } \\
\text { Jazan, Mecca, Al-Medina, Najran, Quassiem, } \\
\text { Riyadh, Tabuk }\end{array}$ \\
\hline 5 & Apistobuthus pterygocercus & Buthidae & Hail \\
\hline 6 & Buthacus leptochelys & Buthidae & $\begin{array}{l}\text { Aseer, Attaif, Eastern R, Hail, Jazan, Al-Medina, } \\
\text { Quassiem, Riyadh }\end{array}$ \\
\hline 7 & Buthacus leptochelys nitzani? & Buthidae & Al-Baha, Al-Gunfuda \\
\hline 8 & Buthacus yotvatensis nigroaculeatus & Buthidae & Eastern R, Hafr Al-Batin, Riyadh \\
\hline 9 & Butheolus arabicus & Buthidae & Jazan \\
\hline 10 & Butheolus gallagheri & Buthidae & Jazan \\
\hline 11 & Butheolus thalassinus & Buthidae & Jazan \\
\hline 12 & Compsobuthus arabicus & Buthidae & $\begin{array}{l}\text { Hafr Al-Batin, Hail, Al-Medina, Quassiem, } \\
\text { Riyadh, Tabuk }\end{array}$ \\
\hline 13 & Compsobuthus arabicus arabicus? & Buthidae & Riyadh \\
\hline 14 & Compsobuthus werneri & Buthidae & $\begin{array}{l}\text { Al-Baha, Aseer, Attaif, Hafr Al-Batin, Jazan, Al- } \\
\text { Medina, Najran, Riyadh, Tabuk, }\end{array}$ \\
\hline 15 & Hottentotta jayakari & Buthidae & Jazan \\
\hline 16 & Leiurus quinquestriatus & Buthidae & $\begin{array}{l}\text { Al-Baha, Al-Gunfuda, Aseer, Eastern R, Hail, } \\
\text { Mecca, Al-Medina, Najran, Riyadh, Attaif, Jazan, } \\
\text { Tabuk }\end{array}$ \\
\hline 17 & Orthochirus innesi & Buthidae & $\begin{array}{l}\text { Al-Baha, Aseer, Eastern R, Hail, Jazan, Al- } \\
\text { Medina, Quassiem, Riyadh, Tabuk }\end{array}$ \\
\hline 18 & Orthochirus scrobiculosus & Buthidae & Hail \\
\hline 19 & Parabuthus liosoma & Buthidae & Al-Gunfuda, Aseer, Jazan \\
\hline 20 & Unidentified & Buthidae & Eastern R \\
\hline 21 & Vachoniolus minipectinibus & Buthidae & Al-Baha, Eastern R \\
\hline 22 & Vachoniolus spp? & Buthidae & Eastern R \\
\hline 23 & Hemiscorpius arabicus & Hemiscorpiidae & Riyadh \\
\hline 24 & Hemiscorpius lepturus? & Hemiscorpiidae & Riyadh \\
\hline 25 & Nebo hierichonticus & Scorpionidae & $\begin{array}{l}\text { Al-Baha, Aseer, Attaif, Jazan, Al-Medina, Najran, } \\
\text { Tabuk }\end{array}$ \\
\hline 26 & Scorpio maurus fuscus & Scorpionidae & Al-Baha, Aseer, Attaif, Jazan, Najran, \\
\hline 27 & Scorpio maurus kruglovi & Scorpionidae & $\begin{array}{l}\text { Hafr Al-Batin, Hail, Al-Medina, Quassiem, } \\
\text { Riyadh, Tabuk }\end{array}$ \\
\hline 28 & Scorpio maurus palmatus? & Scorpionidae & Attaif, Hail, Tabuk \\
\hline
\end{tabular}

\section{The Jazan region}

The scorpions of Jazan (including the Forsan Isles) were identified as 12 species and subspecies (Figure 6). Three species were new records for the region (Butheolus arabicus, Butheolus thalassinus and Butheolus gallagheri). There were six black species (Androctonus crassicauda, Nebo hierichonticus, Orthochirus innesi, Butheolus arabicus, Butheolus thalassinus and Butheolus gallagheri), ranging in length from 2.1 (Orthochirus) to $13.5 \mathrm{cms}$ (Nebo). Nebo hierichonticus (Scorpionidae) is implicated in serious outcomes including death (Annobil, 1993, Annobil et al., 1991) even though its venom toxicity is not very high.

Buthidae Koch, 1837

Parabuthus Pocock, 1890

Parabuthus liosoma H. and E., 1829

Hottentotta Birula, 1908

Hottentotta jayakari salei Pocock, 1895 
Compsobuthus Vachon, 1949

Leiurus H. and E., 1829

Buthacus Birula, 1908

Orthochirus Karsch, 1891

Butheolus Simon, 1882

Androctonus Ehrenberg, 1828

Scorpionidae Pocock, 1893

Nebo Simon, 1878

Scorpio Linnaeus, 1758
Compsobuthus werneri Birula, 1908

Leiurus quinquestriatus H. and E., 1828 and 1829

Buthacus leptochelys Ehrenberg, 1829

Orthochirus innesi Simon, 1910

Butheolus arabicus Simon, 1882

Butheolus thalassinus Simon, 1882

Butheolus gallagheri Vachon, 1980

Androctonus crassicauda Olivier, 1807

Nebo hierichonticus Simon, 1878

Scorpio maurus fuscus H. et E., 1829

Figure 6: The scorpion species collected from the Jazan region including the Forasan Isles.

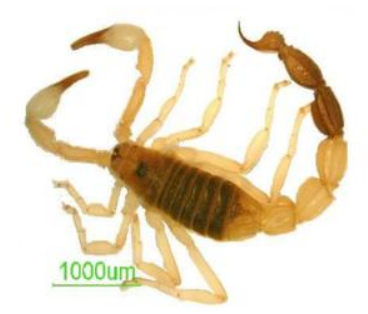

Parabuthus liosoma (ぶ)

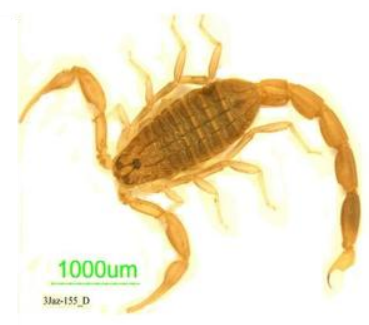

Compsobuthus werneri (ㅇ)
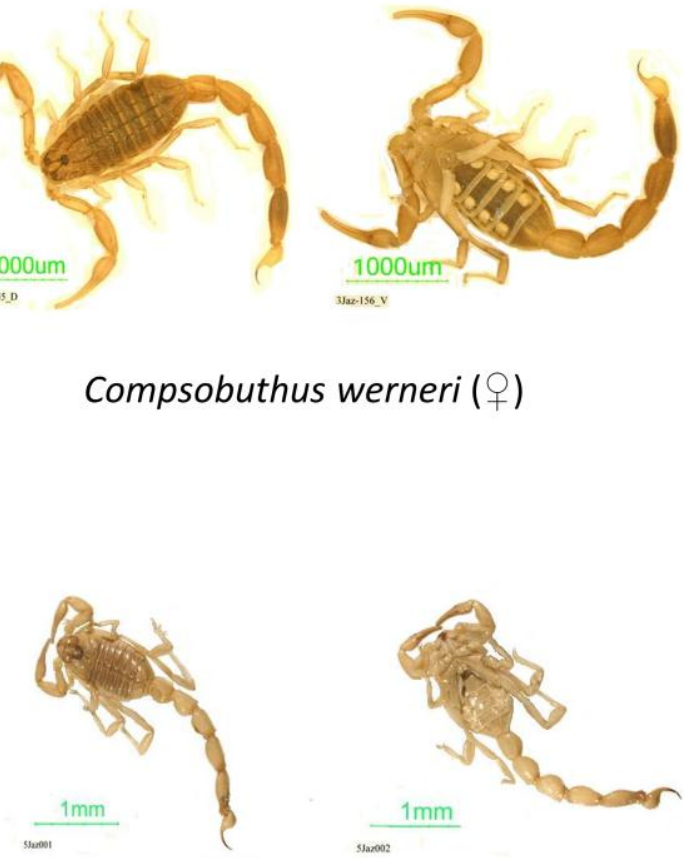

$\frac{1000}{3 \text { antis }} \mathrm{v}$

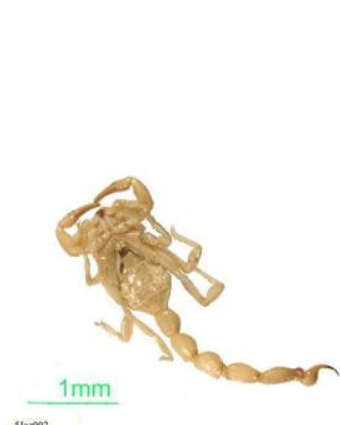

Buthacus leptochelys (ठ)

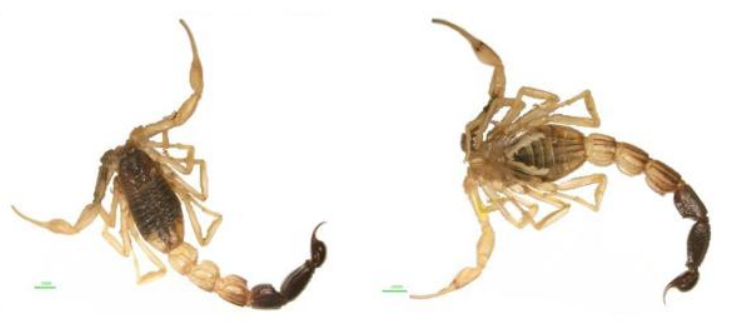

Hottentotta jayakari salei (ठ̂)
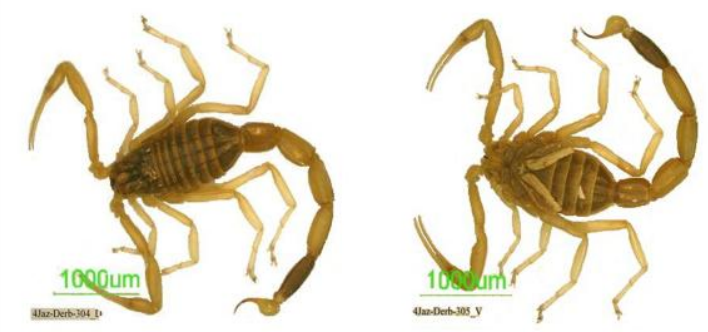

Leiurus quinquestriatus (へ) 


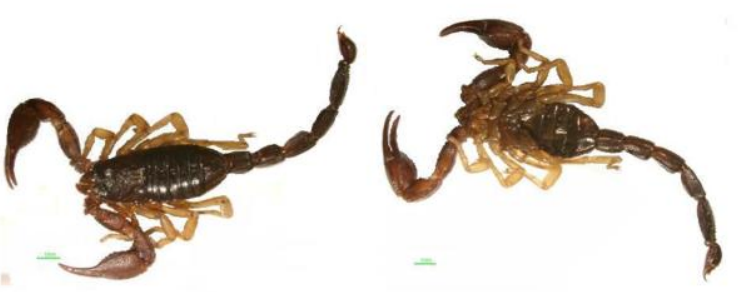

Nebo hierichonticus (つิ)

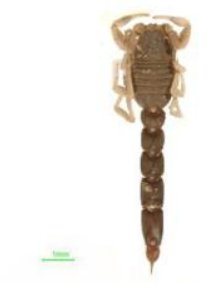

Butheolus thalassinus (ठึ)

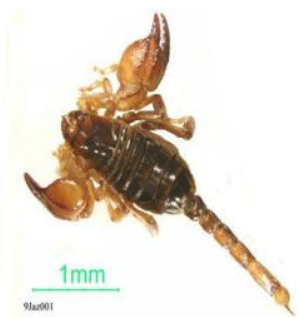

Scorpio maurus fuscus (ふ̋)

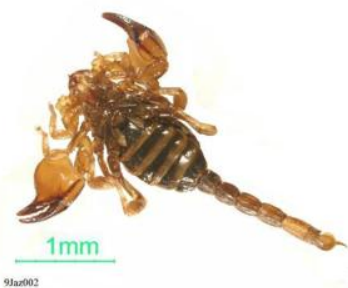

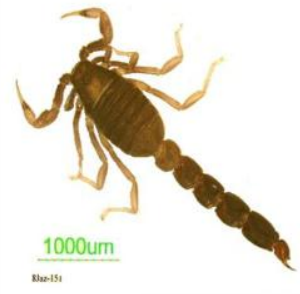

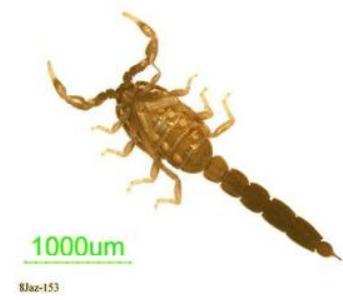

Butheolus arabicus (ठ)

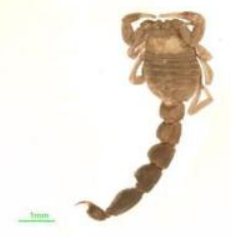

Butheolus gallagheri $\left({ }^{\top}\right)$

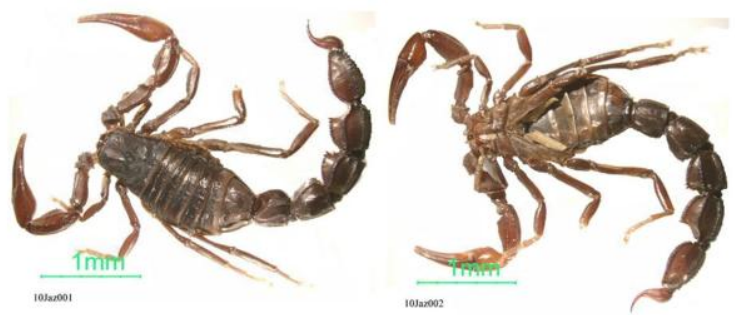

Androctonus crassicauda ( + )

\section{The Al-Medina Al-Munawara region}

The scorpions of this region comprised nine species and subspecies (Figure 7): three of these are black, two large (Androctonus crassicauda at $9.9 \mathrm{cms}$, and Androctonus bicolor at $8.3 \mathrm{cms}$ long) and one smaller (Orthochirus innesi at $2.5-3.3 \mathrm{cms}$ long). All the other species are yellow.

Buthidae Koch, 1837

Leiurus H. and E., 1829

Androctonus Ehrenberg, 1828

Orthochirus Karsch, 1891

Buthacus Birula, 1908

Compsobuthus Vachon, 1949

Androctonus Ehrenberg, 1828
Leiurus quinqestriatus H. and E., 1828 and 1829

Androctonus crassicauda Olivier, 1807

Orthochirus innesi Simon, 1910

Buthacus leptochelys Ehrenberg, 1829

Compsobuthus arabicus Levy et al., 1973

Compsobuthus werneri Birula, 1908

Androctonus australis Linnaeus, 1758 
Scorpionidae Pocock, 1893

Scorpio Linnaeus, 1758
Scorpio maurus kruglovi Birula, 1910

Scorpio maurus palmatus Ehrenberg, 1828

Figure 7: The scorpion species collected from the Al-Medina Al-Munawwara region.

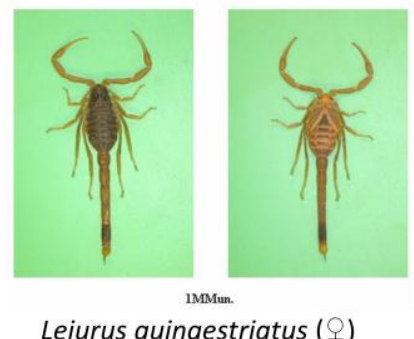

Leiurus quinqestriatus $(q)$

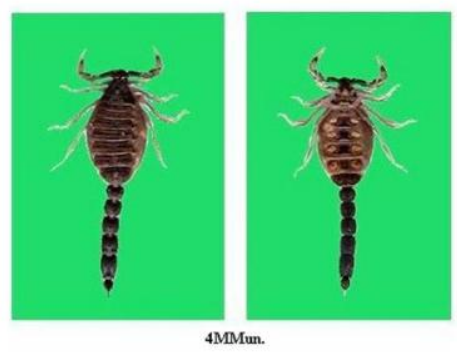

Orthochirus innesi $(+)$

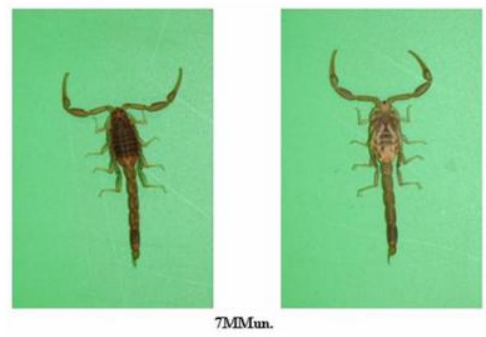

Compsobuthus werneri $\left({ }^{\lambda}\right)$
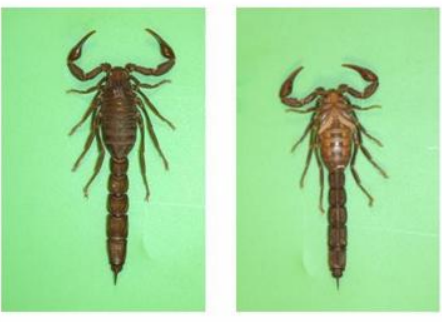

2MMur

Androctonus crassicauda $(q)$

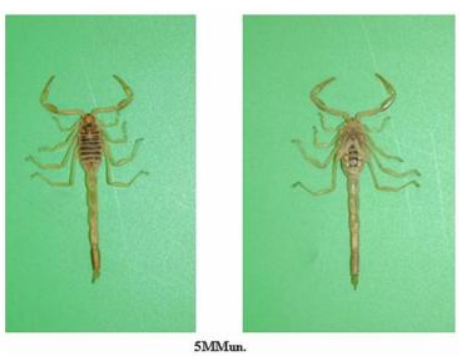

Buthacus leptochelys (q)

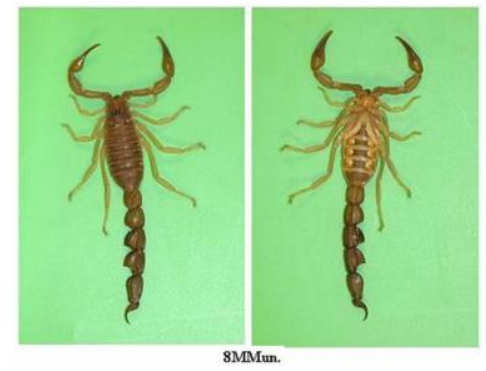

Androctonus australis (q)

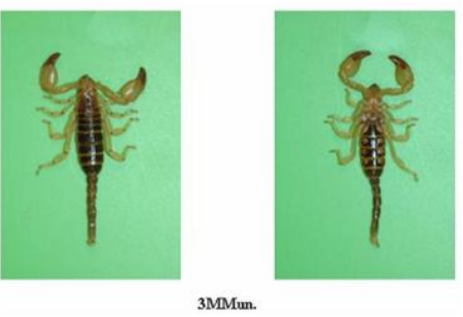

Scorpio maurus kruglovi (ठ઼)

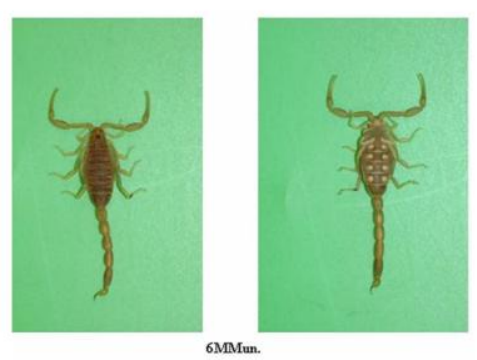

Compsobuthus arabicus (ठํ)
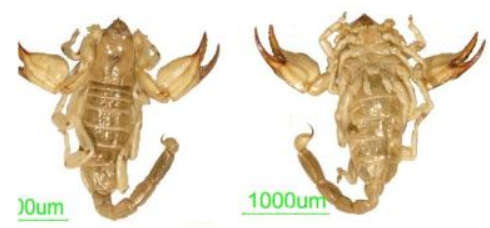

Scorpio maurus palmatus $(q)$

\section{Al-Baha Region}

In this region there were seven species and subspecies (Figure 8), with only two black species, one large (Nebo hierichonticus, mean length $11.3 \mathrm{~cm}$ ) and one small (Orthochirus innesi, 3.2 $\mathrm{cm}$ ); all other species were yellow. Nebo hierichonticus along with hemiscorpiid scorpions lead to complications, intracranial haemorrhage and death (Arachnodata 2009a, 2009b; ITG Library 2009, Annobil 1993, Annobil et al. 1991, Navidpour et al. 2008). Buthacus leptochelys nitzani is reported from cooler places in Palestine, Jordan and Israel, and were found to inhabit similar habitat in Al-Baha and Al-Gunfuda (western Sarawat Ranges) in Saudi Arabia.

\section{Buthidae Koch, 1837}

Leiurus H. and E., 1829

Buthacus Birula, 1908

Compsobuthus Vachon, 1949

Orthochirus Karsch, 1891

Vachoniolus Levy et al., 1973
Leiurus quinquestriatus H. and E., 1828 and 1829

Buthacus leptochelys nitzani

Compsobuthus werneri Birula, 1908

Orthochirus innesi Simon, 1910

Vachoniolus minipectinibus Levy et al., 1973 
Scorpionidae Pocock, 1893

Scorpio Linnaeus, 1758

Nebo Simon, 1878
Scorpio maurus fuscus H. et E., 1829

Nebo hierichonticus Simon, 1878

Figure 8: The scorpion species collected from Al-Baha Region.

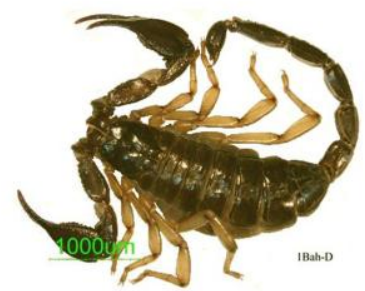

Nebo hierichonticus (q)

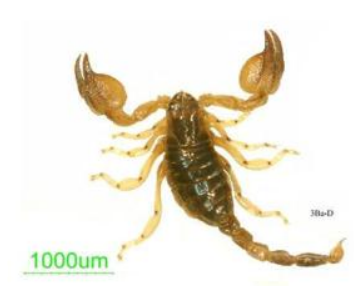

Scorpio maurus fuscus $(+)$
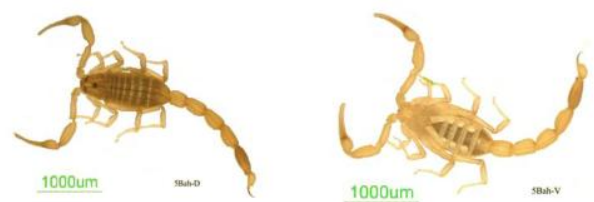

Compsobuthus werneri (さ)

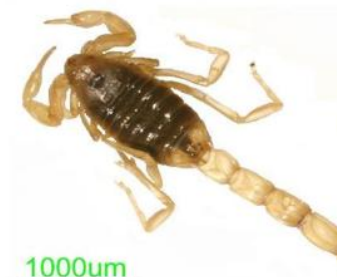

Vachoniolus minipectinibus (q)

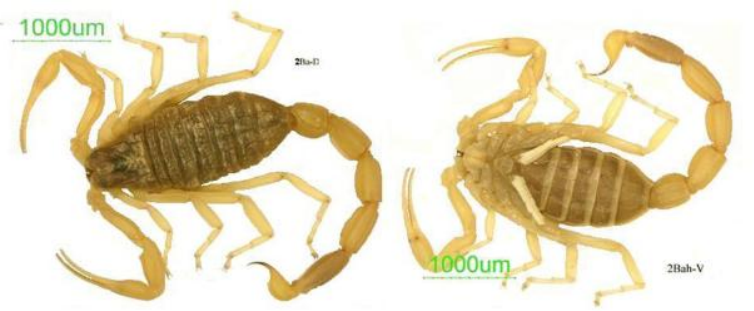

Leiurus quinquestriatus $(\widehat{\jmath})$

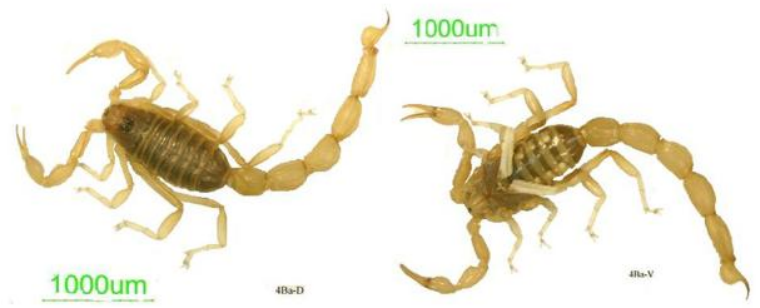

Buthacus leptochelys nitzani ( $(+)$

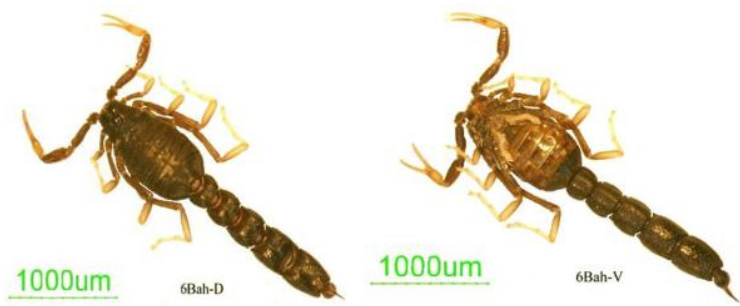

Orthochirus innesi (び)

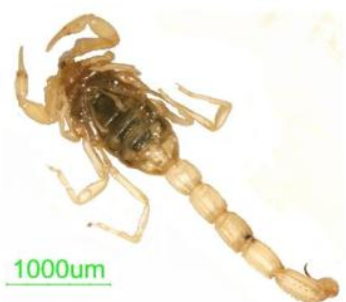

1000um 


\section{Hail Region}

There were 10 species and subspecies in this region (Figure 9), including one new record, Orthochirus scrobiculosus. The subspecies Orthochirus scrobiculosus persa is found on the eastern side of the gulf (Iran), but we do not know yet whether the Hail specimens belong to this subspecies. Three were black species, two large (Androctonus crassicauda $8.5 \mathrm{cms}$ and Androctonus bicolor $8.3 \mathrm{cms}$ in length) and two smaller (Orthochirus innesi and Orthochirus scrobiculosus (both $2.8-3.0 \mathrm{~cm}$ long). All the other species are yellow.

\section{Buthidae Koch, 1837}

Androctonus Ehrenberg, 1828

Androctonus crassicauda Olivier, 1807

Androctonus bicolor Ehrenberg, 1828

Orthochirus Karsch, 1891

Compsobuthus Vachon, 1949

Orthochirus innesi Simon, 1910

Compsobuthus arabicus Levy et al., 1973

Buthacus Birula, 1908

Leiurus H. and E., 1829

Apistobuthus Finnegan, 1932

Orthochirus Karsch, 1891

Buthacus leptochelys Ehrenberg, 1829

Leiurus quinquestriatus H. and E., 1828 and 1829

Apistobuthus pterygocercus Finnegan, 1932

Orthochirus scrobiculosus Grube, 1873

\section{Scorpionidae Pocock, 1893}

Scorpio Linnaeus, 1758

Scorpio maurus kruglovi Birula, 1910

Scorpio maurus palmatus Ehrenberg, 1828

Figure 9: The scorpion species collected from Hail region.

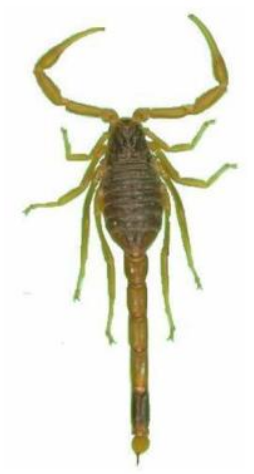

Leiurus quinquestriatus $(ð)$
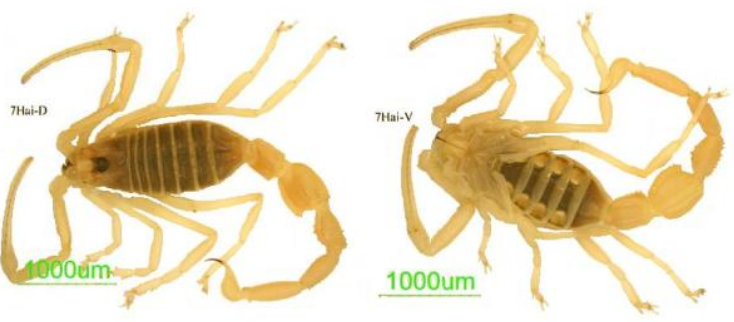

Apistobuthus pterygocercus (q)

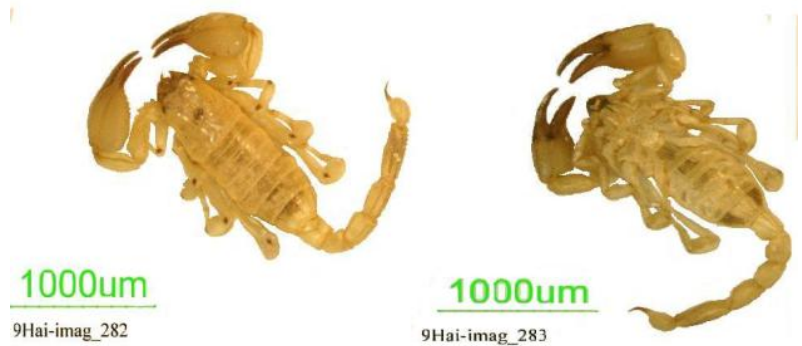

Scorpio maurus palmatus $(\widehat{\jmath})$

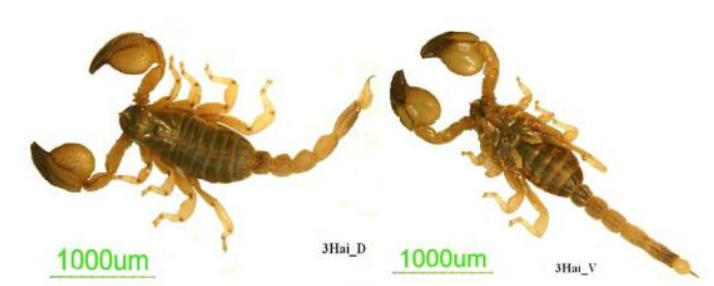

Scorpio maurus kruglovi ( $(+)$ 


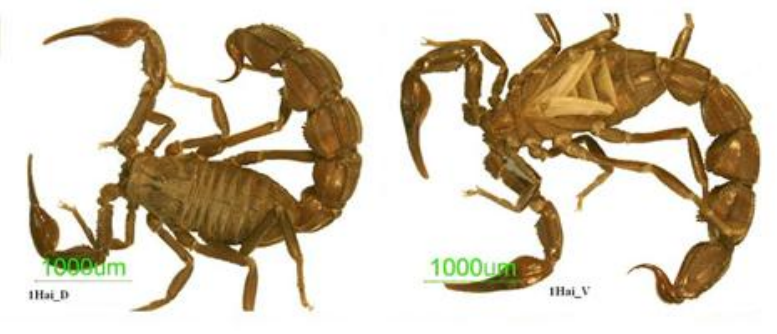

Androctonus crassicauda (q)

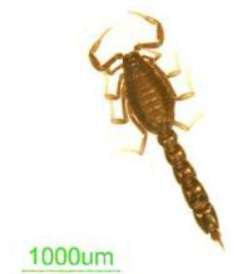

Orthochirus scrobiculosus (q)

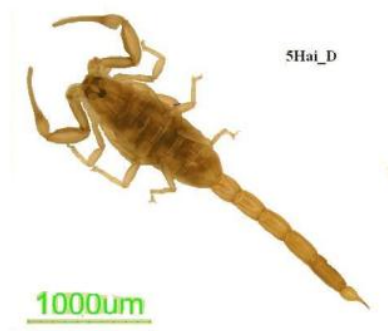

Compsobuthus arabicus (ふึ)

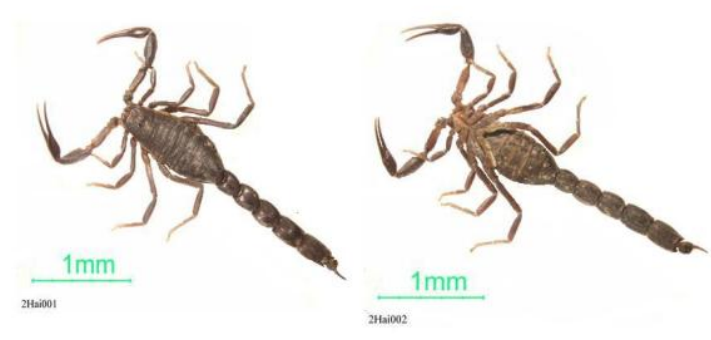

Androctonus bicolor $(ふ)$
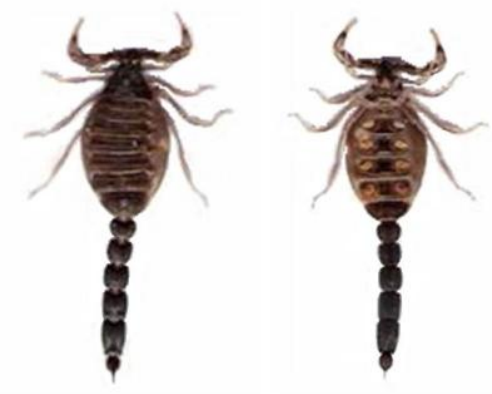

Orthochirus innesi ( $९$ )

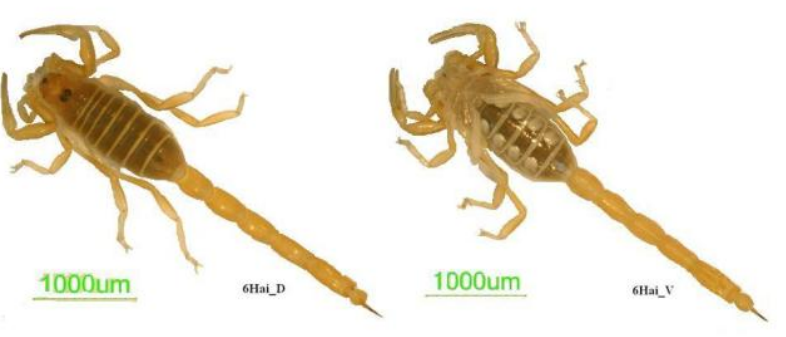

Buthacus leptochelys (つ゚)

\section{Riyadh region}

Twelve species and subspecies were recognised from the Riyadh region (Figure 10), including three black buthids (Androctonus crassicauda 9.5-11 cms long, Androctonus bicolor 7.4-8.6 cms and Orthochirus innesi 2.1-3.3 cms), two of which are medically important but the small Orthochirus innesi is not. All three families were represented, although the scorpionid Scorpio maurus kruglovi and the hemiscorpiid Hemiscorpius arabicus only occurred at very low densities; two species are as yet unidentified. The two Androctonus species and Hemiscorpius arabicus have not been recorded from elsewhere in Saudi Arabia. A third medically important species occurs, albeit at low densities, namely Leiurus quinquestriatus, famously dangerous worldwide, known as the "Death Stalker" or the lethal killer. All three species are highly venomous (Beaver, 1981, Dittrich et al., 1995, Simard \& Watt, 1990, Karatas \& Colak, 2005) and hence their high medical importance.

One of the three hemiscorpiid specimens had stung a patient in the Riyadh region, who was then hospitalized in with a serious medical outcome. This specimen is still unconfirmed to species (Hemiscorpius lepturus?). More specimens, in good condition are required to accomplish full identification. Recent reports and personal contacts from the Adduraihmia 
sector on the periphery of Riyadh City provide preliminary information about the existence of a population of this genus.

Hemiscorpius lepturus is only known from nearby on the eastern side of the Gulf, i.e. the southern provinces (especially Khuzestan) of Iran: it is well known for producing medical complications that include haemolysis, renal failure and coma with extensive damage to the skin and subcutaneous tissue (Arachnodata 2009a, 2009b; Navidpour et al. 2008, Halse et al. 1980). Verification and comparative work on these two species awaits further surveys.

Two buthids (Compsobuthus werneri and Orthochirus innesi) are rare, whilst three others are rather more frequent (Compsobuthus arabicus, Buthacus yotvatensis nigroaculeatus and Buthacus leptochelys). The toxicity of these less common species demands further clarification, though several investigators (Arachnodata 2009a, Karatas \& Colak 2005, Koch 1977, Lamoral 1980, Levy \& Amitai 1980, Karatas 2003, Kovarik 2005, Teruel \& Tietz 2008) have described their toxicity elsewhere.

Buthidae Koch, 1837

Leiurus H. and E., 1829

Compsobuthus Vachon, 1949

Androctonus Ehrenberg, 1828

Buthacus Birula, 1908

Buthacus Birula, 1908

Orthochirus Karsch, 1891

Scorpionidae Pocock, 1893

Scorpio Linnaeus, 1758

Hemiscorpiidae Pocock, 1893

Hemiscorpius Peters, 1861
Leiurus quinquestriatus $\mathrm{H}$. and E., 1828 and 1829

Compsobuthus arabicus Levy et al., 1973

Compsobuthus werneri Birula, 1908

Compsobuthus arabicus arabicus Levy et al., 1973

Androctonus crassicauda Olivier, 1807

Androctonus bicolor Ehrenberg, 1828

Buthacus yotvatensis nigroaculeatus Levy et al., 1973

Buthacus leptochelys Ehrenberg, 1829

Orthochirus innesi Simon, 1910

Scorpio maurus kruglovi Birula, 1910

Hemiscorpius arabicus Pocock, 1899

Hemiscorpius lepturus? Peters, 1861

Figure 10: The scorpion species collected from the Riyadh region

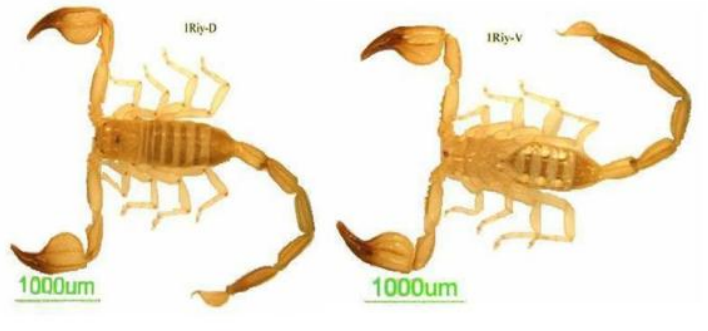

Hemiscorpius arabicus ()
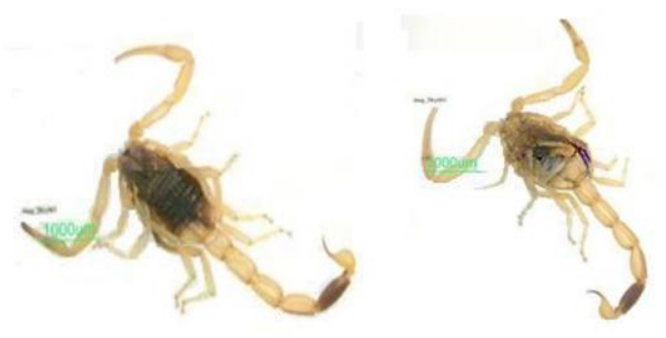

Leiurus quinquestriatus (ठ) 


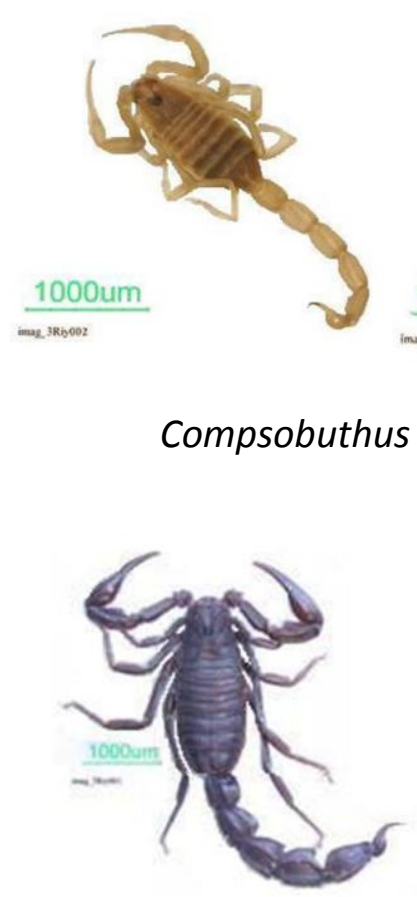

Androctonus crassicauda (†)
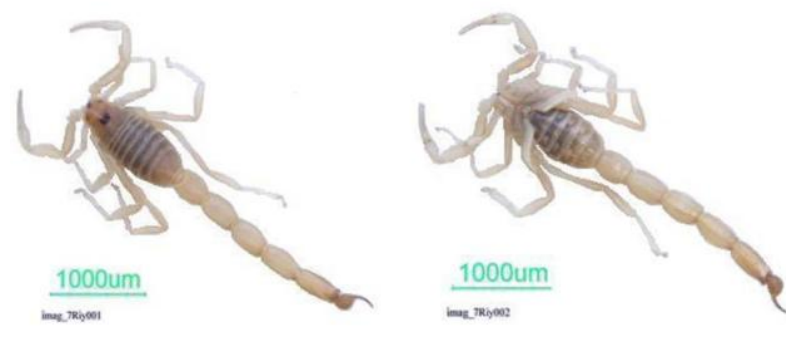

Buthacus yotvatensis nigroaculeatus (P)

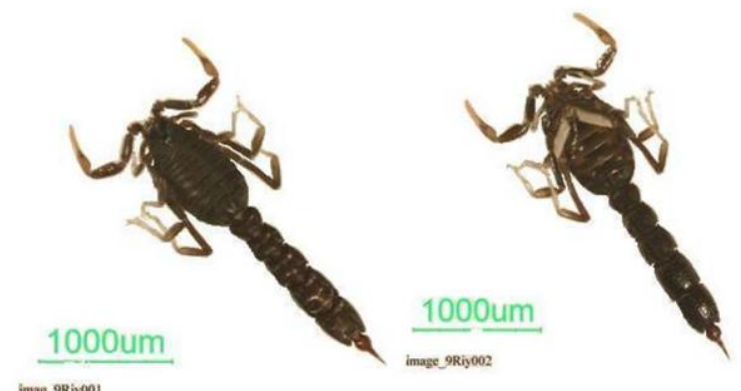

Orthochirus innesi ()

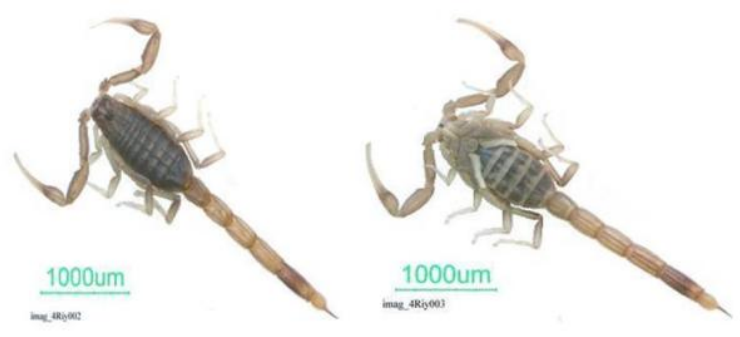

Compsobuthus werneri $\left({ }^{\widehat{C}}\right)$

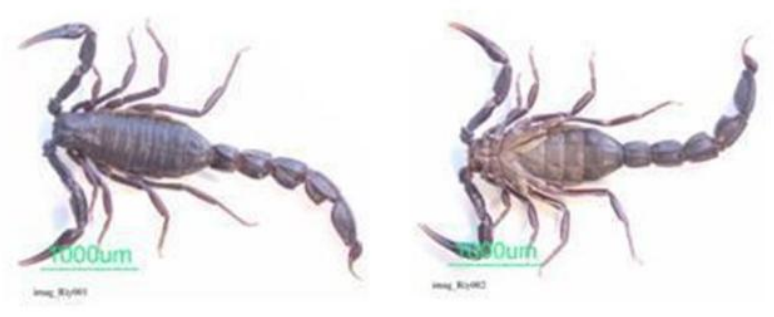

Androctonus bicolor $(\hat{0})$

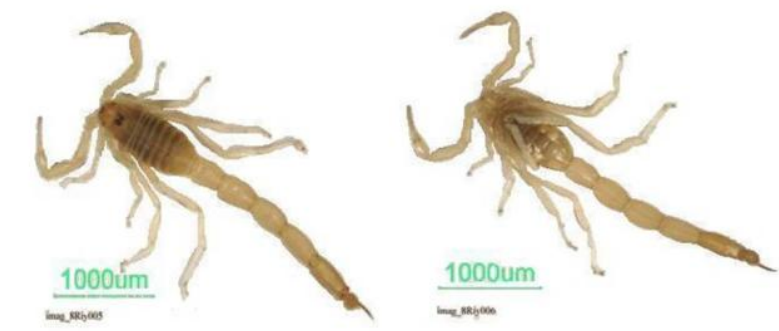

Buthacus leptochelys (ふ)

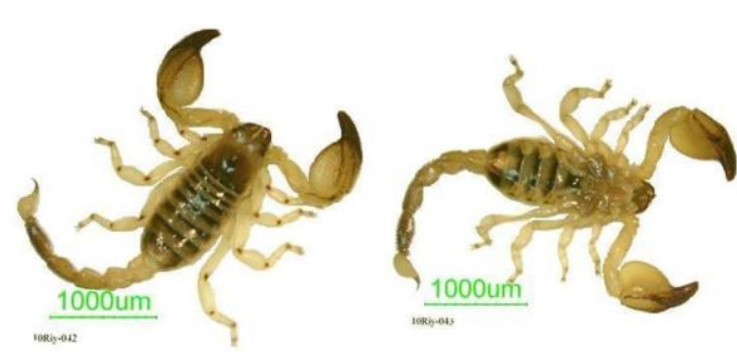

Scorpio maurus kruglovi $\left({ }^{\lambda}\right)$ 
Some specimens, such as Compsobuthus arabicus arabicus? (Riyadh region), Hemiscorpius lepturus? and Vachoniolus spp?, could not be identified to species and subspecies due to their damage, and new specimens will be necessary to confirm their identity.

\section{Scorpion venom glands}

We studied the venom glad morphology of some of the scorpions that were collected (cf. AlAsmari et al. 2007, 2009a). Venom glands have been studied extensively (Pavlovsky 1912, Lourenco 1985, Polis 1990, Taib \& Jarrar 1993, Jarrar \& Al-Rowaily 2008, Yigit \& Benli 2008) for their histology, histochemistry and characters for higher-level taxonomy (Keegan \& Lockwood 1971, Mazurkiewicz \& Bertke 1972, Halse et al. 1980, Kanwar et al. 1981, Cebesoy \& Ayvali 2003). Venom profiles have been studied for their physicochemical and biological characteristics, especially in their effects on ion channels (Gantenbein et al. 1999, Kovarik 2005), and recent work has involved Saudi Arabian scorpions (Al-Asmari et al., in press). Scorpion venom components are known to be active and effective as antimicrobials (Zamudio et al. 1997, Possani et al. 1999, Torres-Larios et al. 2000, Zeng et al. 2001, 2004; Moerman et al. 2002).

Figure 11 illustrates the structure of scorpion venom glands from specimens collected from the Al-Baha region. The cross section of the Compsobuthus werneri telsa (Buthidae) reflects complexly folded glands, while those of Scorpio maurus fuscus and Nebo hierichonticus (Scorpionidae) show no or only simple folding, but the cuticle of Nebo is very thick. The telsa section of Leiurus quinqestriatus (Buthidae) showed very distinct complexly folded glands.

Figure 11: Cross sections of the telsa (venom glands) of scorpions collected from Al-Baha.

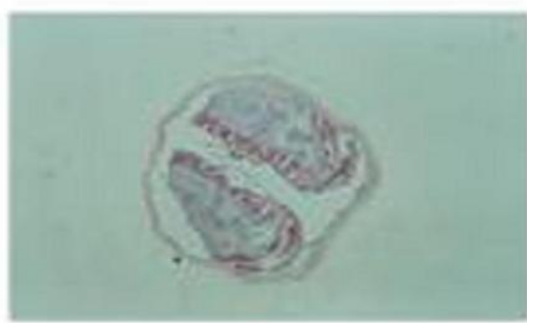

A. Compsobuthus werneri

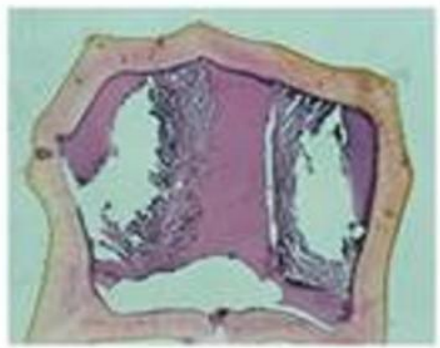

C. Nebo hienchonticus

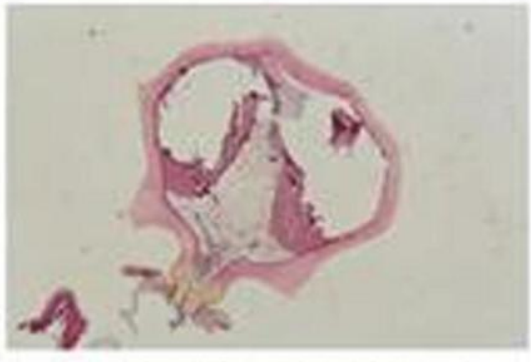

B. Scorpio maurus fuscus

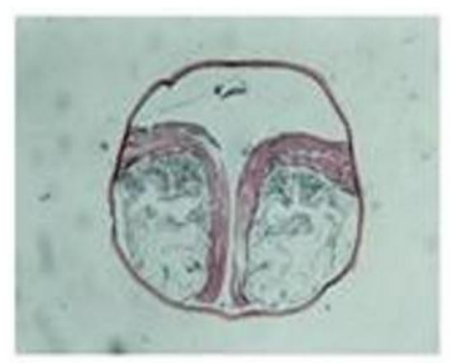

D. Leiurus quingestriatus 
Figure 12 shows the structure of scorpion venom glands from specimens collected from Hail. The cross sections of Buthacus leptochelys and Compsobuthus werneri (Buthidae) again reflect complexly folded glands, whilst that of Scorpio maurus kruglovi (Scorpionidae) showed no or only simple folding. Sections of Leiurus quinqestriatus (Buthidae) showed very distinct complexly folded glands similar to those of the buthid species Androctonus crassicauda and Androctonus bicolor.

Figure 12: Cross sections of the telsa (venom glands) of scorpions collected from Hail region.

\section{A. Buthacus leptochelys}

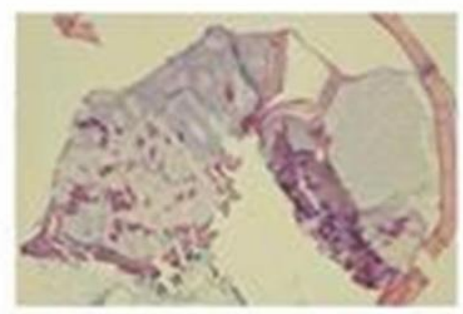

C. Scorpio maurus kruglovi

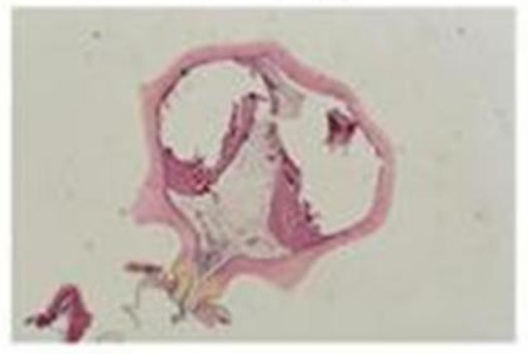

E. Leiurus quingestriatus

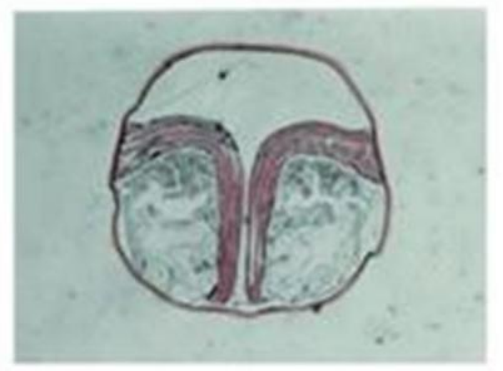

\section{B. Compsobuthus werneri}

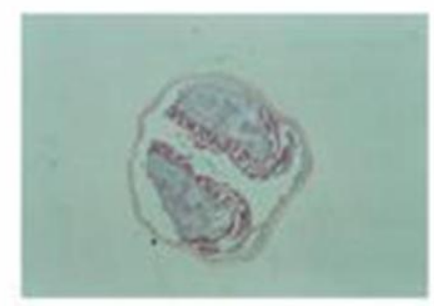

D. Androctomus crassicauda

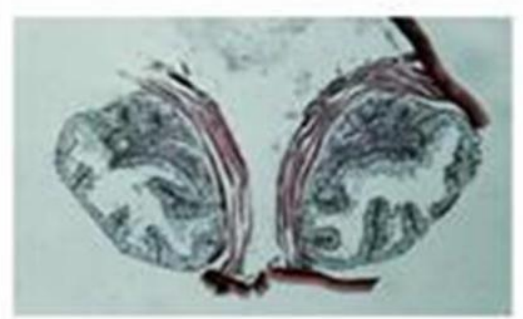

F. Androctonus bicolor

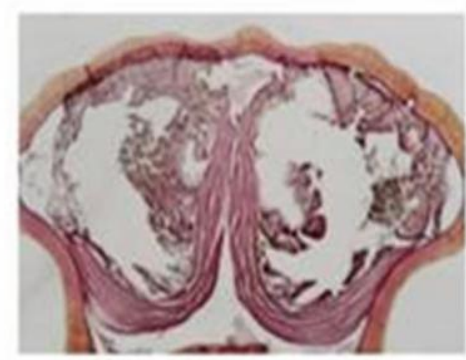

Figure 13 shows the structure of scorpion venom glands from specimens collected from the Riyadh region. The cross sections of the buthids Compsobuthus arabicus, Compsobuthus werneri, Leiurus quinqestriatus, Androctonus crassicauda, Androctonus bicolor, Buthacus yotvatensis nigroaculeatus, Buthacus leptochelys and Orthochirus innesi all reflect complexly folded glands. Those of Leiurus quinqestriatus, Androctonus crassicauda and Androctonus 
bicolor showed very distinct and densely folded glands. The section of the scorpionid Scorpio maurus kruglovi showed no or only simple folding, with very thick cuticle.

Figure 13: Cross sections of the telsa (venom glands) of scorpions collected from the Riyadh region.

C. Leiurus quinqestriatus $\mathrm{C}(2)$. Leiurus quinqestriatus
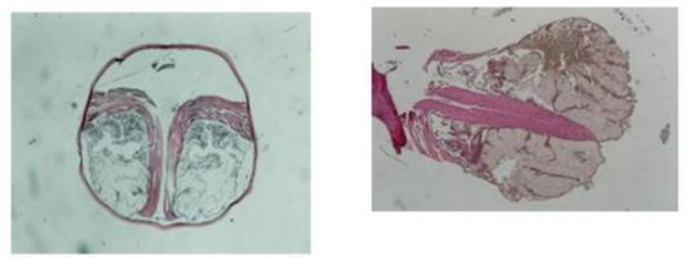

D. Androctonus crassicauda. D (2). Androctonus crassicauda
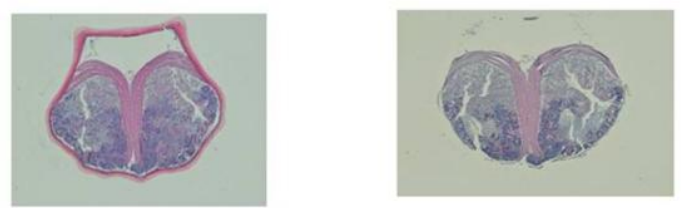

E. Androctonus bicolor.

E (2). Androctonus bicolor
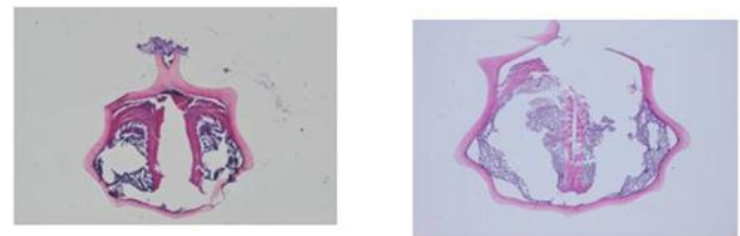

B. Compsobuthus werneri

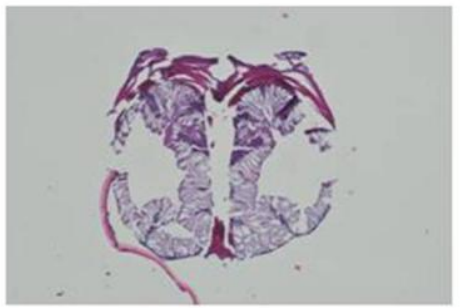

A. Compsobuthus arabicus.

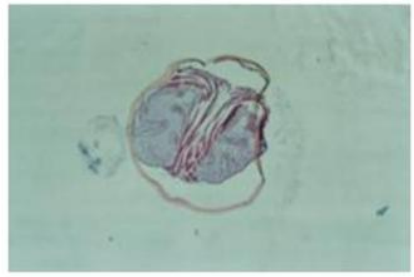

Buthacus yotvatensis nigroaculeatus

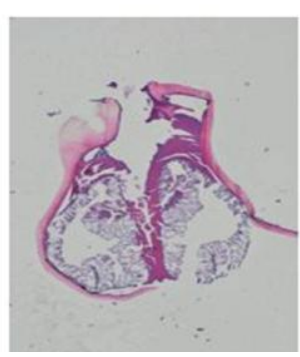

H. Orthochirus innesi

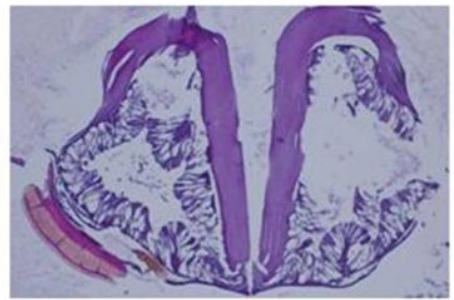




\section{References}

Al-Asmari AK, Al-Saif AA \& Abdo NM (2007) Morphological identification of scorpion species from Jazan and Al-Medina Al-Munawwara Regions, Saudi Arabia. Journal of Venomous Animals \& Toxins including Tropical Diseases 13(4): 821-843

Al-Asmari AK, Al-Saif AA, Abdo NM \& Al-Moutaery KR (2009a) The scorpion fauna of Al-Baha and Hail Regions, Saudi Arabia. Journal of Biological Sciences 9: 96-108

Al-Asmari AK, Al-Saif AA, Abdo NM \& Al-Moutaery KR (2009b) New additions to the scorpion fauna of Riyadh region, Saudi Arabia. Journal of Venomous Animals \& Toxins including Tropical Diseases 15(4): 612-632

Al-Hajjaj A (2005) Scorpions in the Arab World and rest of the Globe. 1st edn. Daraldia, Amman.

Al-Sadoon M \& Al-Farraj S (2008) Scorpions in the Kingdom of Saudi Arabia. 2nd edn. Al-Jeraisy, Riyadh.

Annobil S (1993) Scorpion stings in children in the Asir Province of Saudi Arabia. Journal of Wilderness Medicine (now Wilderness \& Environmental Medicine) 4: 241-251

Annobil S, Omojola M \& Vijayakumar E (1991) Intracranial haemorrhages after Nebo hierichonticus scorpion sting. Annals of Tropical Paediatrics 11(4): 377-380

Arachnodata (2009a) The specialized Website of Arachnology. http://www.arachnodata.ch

Arachnodata (2009b) Scorpionism in Iran. http://www.arachnodata.ch/projects.htm\#iran

Beaver P (1981) Scorpions of medical importance. American Journal of Tropical Medicine \& Hygiene 30(3): 745-746

Cebesoy S \& Ayvali C (2003) Myotis myotis 'in (Borkhausen) Esas Uçma Kaslarýnda Morfolojik ve Histokimyasal Araptirmalar. Gazi University Journal of Science 2003: 245-252

Dittrich K, Power A \& Smith N (1995) Scorpion sting syndrome - a ten-year experience. Annals of Saudi Medicine 15: 148-155

El-Hennawy HK (2009) Scorpions of Saudi Arabia (List of species, their distribution, and identification key). Serket 11(34): 119-128

Euscorpius (2009) The specialized Website of Scorpiology. www.science.marshall.edu/fet/euscorpius/p2009.

Fet V \& Bechly G (2000) Ischnurainae Fraser, 1957 (Insecta, Odonata): proposed conservation as the correct spelling of Ischnurinae to remove homonymy with Ischnuridae Simon, 1879 (Arachnida, Scorpiones). Bulletin of Zoological Nomenclature 57(I), 26-28

Fet V \& Braunwalder M (2000) The scorpions (Arachnida, Scorpiones) of the Aegean area: current problems in taxonomy and biogeography. Belgian Journal of Zoology 130: 17-22

Fet V \& Soleglad M (2005) Contributions to scorpion systematics. I: On recent changes in high level taxonomy. Euscorpius 31: 113

Fet V, Gantenbein B, Karatas A \& Karatas A (2005) An extremely low genetic divergence across the range of Euscorpius italicus (Scorpiones: Euscorpiidae). Journal of Arachnology 34: 248-253

Fet V, Karatas A, Fet EV \& Karatas A (2003) First data on the molecular phylogeny of Euscorpius (Scorpiones: Euscorpiidae) from Turkey. Entomological Review 83: 249-252

Fet V \& Lowe G (2000) Family Buthidae. In: Fet V, Sissom W, Lowe G \& Braunwalder M (eds). Catalog of the Scorpions of the World (1758-1998). 690 pp. The New York Entomological Society, New York. http://cosserver.marshall.edu/euscorpius/Fet.htm

Fet V, Soleglad M \& Lowe G (2005) A new trichobothrial character for the high-level systematics of Buthoidea (Scorpiones: Buthida). Euscorpius 23: 1-40

Froufe E, Sousa P, Paulo C \& Harris ADJ (2008) Genetic diversity within Scorpio maurus (Scorpiones: Scorpionidae) from Morocco: preliminary evidence based on CO1 mitochondrial DNA sequences. Biologia 63(6): 1157-1160

Gantenbein B, Fet V, Largiadèr CR \& Scholl A (1999) First DNA phylogeny of Euscorpius Thorell, 1876 (Scorpiones: Euscorpiidae) and its bearing on taxonomy and biogeography of this genus. Biogeographica 75(2): 49-65

Gromov AV (1998) A new family, genus and species of scorpions (Arachnida, Scorpiones) from southern Central Asia. Zoologicheskij zhurnal 77(9) : 1003-1008

Halse SA, Prideaux PL, Cockson A \& Zwicky KT (1980) Observations on the morphology and histochemistry of the venom glands of a scorpion, Urodacus novaehollandiae Peters (Scorpionidae). Australian Journal of Zoology 28: 185-194

Hendrixson BE (2006) Buthid scorpions of Saudi Arabia, with notes on other families (Scorpiones: Buthidae, Liochelidae, Scorpionidae). Fauna Arabia 21: 33-120

Hendrixson BE (2002) Systematic studies on the scorpiofauna of Saudi Arabia (Scorpiones: Buthidae, Diplocentridae, Hemiscorpiidae, Scorpionidae) MSc Thesis, 193 pp. A \& M University West Texas.

Hendrixson BE (2008) The Bond Lab. http://core.ecu.edu/biol/bondja/hendrixson.html

ITG Library (2009) Scorpions.5.1:taxonomy http://www.itg.be/itg/DistanceLearning/LectureNotesVanden EndenE/43_Scorpionsp5.htm 
Jarrar BM \& Al-Rowaily MA (2008) Histology and histochemistry of the venom apparatus of the black scorpion Androctonus crassicauda (Olivier, 1807) (Scorpiones: Buthidae). Journal of Venomous Animals \& Toxins including Tropical Diseases 14(3): 514-526

Kanwar U, Sharma A \& Nagpal N (1981) Morphological and cytochemical studies on the venom secreting cells of the scorpion Buthus tamulus. Journal of Animal Morphology \& Physiology 28(1): 206-209

Karatas A (2003) New records on the occurrence of Hottentotta saulcyi Simon 1880 (Scorpiones: Buthidae) in Turkey. Israel Journal of Zoology 49: 315-316

Karatas A \& Colak M (2005) Scorpions of Gaziantep Province, Turkey (Arachnida: Scorpiones). Euscorpius 30: $1-7$

Keegan HL (1980) Scorpions of medical importance. Univ. Pr. Mississippi. 152 pp.

Keegan LH \& Lockwood WR (1971) Secretory epithelium in venom glands of two species of scorpion of the genus Centruroides Marx. American Journal of Tropical Medicine \& Hygiene 20: 770-785

Koch LE (1977) The taxonomy, geographic distribution and evolutionary radiation of Australo-Papuan scorpions. Records of the Western Australian Museum 5: 83-367

Kovarik F (2005) Taxonomic position of species of the genus Buthacus Birula, 1908 described by Ehrenberg and Lourenco, and description of a new species (Scorpiones: Buthidae). Euscorpius 28: 1-13

Krauss O (1976) Zur phylogenetischen Stellung und Evolution der Chelicerata. Entomologia Germanica 3: 1-12

Lamoral BH (1980) A reappraisal of the suprageneric classification of recent scorpions and their zoogeography. In: Gruber J (ed), Internationaler Arachnologen-Kongress abgehalten ander Universitat fur Bodenkultur. Wien, 8, Verhandlungen, 1980, pp. 439-444. H. Egermann, Vienna.

Lazarovici P, Yanaig P, Pelhaten M \& Zlotkin E (1982) Insect toxic components from the venom of a chactoid scorpion, Scorpio maurus palmatus (Scorpionidae). Journal of Biological Chemistry 257(14): 8397-8404

Levy G \& Amitai P (1980) Fauna Palaestina: Arachnida. I: Scorpiones. Jerusalem: The Israel Academy of Sciences and Humanities $130 \mathrm{pp}$.

Lourenco WR (1985) Essai d'interpretation de la distribution du genere Opisthocanthus (Arachnida, Scorpiones, Ischnuridae) dan les region Neotropicale et Afrotropicale : étude taxonomique, biogeographique, evolutive et ecologique. PhD Thesis, L'Universite Pierre et Marie Curie, Paris. 287 pp.

Lourenço WR (2008) Parthenogenesis in scorpions: some history - new data. Journal of Venomous Animals \& Toxins including Tropical Diseases 14(1): 19-44

Lourenço WR, Cloudsley-Thompson JL \& Cuellar O (2000) A review of parthenogenesis in scorpions with a description postembryonic development in Tityus metuendus (Scorpiones, Buthidae) from Western Amazonia. Zoologischer Anzeiger 239: 267-276

Lourenço WR, Cloudsley-Thompson JL, Cuellar O, Von Eickstedt VRD, Barraviera B \& Knox MB (1996) The evolution of scorpionism in Brazil in recent years. Journal of Venomous Animals \& Toxins including Tropical Diseases 2: 121-134

Lourenço WR \& Cuellar O (1994) Notes on the geography of parthenogenetic scorpions. Biogeographica 70: 1923

Lyon WF (1991) Rearing mealworms. Classification of the beetle (mealworm insect). http://ohioline.osu.edu/ hyg-fact/2000/2135.html

Lyon WF (1997) Darkling beetle/ Mealworm information. http://insected.arizona.edu/mealinfo.htm

Manton SM (1977) The Arthropoda: habits, functional morphology, and evolution. Clarendon Press, Oxford.

Mazurkiewicz JE \& Bertke EM (1972) Ultrastructure of the venom gland of the scorpion, Centruroides sculpturatus (Ewing). Journal of Morphology 137: 352-83

Moerman L, Bosteels S, Noppe W, Willems J, Clynen E, Schoofs L, Thervissen K, Tygat J, Van Eldere J, Van der Walt J \& Verdenck F (2002) Antibacterial and antifungal properties of alpha-helical, cationic peptides in the venom of scorpions from southern Africa. European Journal of Biochemistry 268: 4799-4810

Navidpour S, Kovarik F, Fet V \& Soleglad ME (2008) Scorpions of Iran (Arachnida, Scorpiones). Part I. Khoozestan Province. Euscorpius 65: 1-41

Operation Scorpion (2010) General introduction to Scorpions. The family Scorpionidae. http://library. thinkquest.org/27858/general.htm

Pavlovsky EN (1912) Studies on the organization and development of scorpions. Quarterly Journal of Microscopical Science $68: 615-643$

Polis GA (1990) The biology of scorpions. 1st ed. Stanford University Press, Stanford.

Possani LD, Beceril B, Delepierre M \& Tytgat J (1999) Scorpion toxins specific for $\mathrm{Na}^{+}$channels. European Journal of Biochemistry 264(2): 287-300

Prendini L (2000) Phylogeny and classification of the superfamily Scorpionoidea Latreille 1802 (Chelicerata, Scorpiones): an exemplar approach. Cladistics 16(1): 1-78

Prendini L (2001) Two new species of Hadogenes (Scorpiones, Ischnuridae) from South Africa, with a redescription of Hadogenes bicolor and a discussion of the phylogenetic position of Hadogenes. Journal of Arachnology 29: 146-172 
Prendini L (2003a) A new genus and species of bothriurid scorpion from the Brandberg Massif, Namibia, with a reanalysis of bothriurid phylogeny and a discussion of the phylogenetic position of Lisposoma Lawrence. Systematic Entomology 28: 149-172

Prendini L (2003b) Revision of the genus Lisposoma Lawrence, 1928 (Scorpiones, Bothriuridae). Insect Systematics \& Evolution 34: 241-164

Prendini L \& Wheeler W (2005) Scorpion higher phylogeny and classification, taxonomic anarchy, and standards for peer review in online publishing. Cladistics 21: 446-494

Rosin R (1965) A new type of poison gland found in the scorpion Nebo hierichonticus (E. Sim.) (Diplocentridae, Scorpiones). River Parasitology 26: 111-122

Rosin R (1969a) Effects of the venom of the scorpion Nebo hierichonticus on white mice, other scorpions and paramecia. Toxicon 7: 71-73

Rosin R (1969b) Note on the alpha-hemolytic effect of the venom of the scorpion Nebo hierichonticus. Toxicon 6: $225-226$

Rosin R (1973) Paper electrophoresis of the venom of the scorpion Nebo hierichonticus (Diplocentridae). Toxicon 11: 107-108

Savory TH (1971) Evolution in the Arachnida. Merrow, Bath

Shultz JW (1990) Evolutionary morphology and phylogeny of Arachnida. Cladistics 6(1): 1-138

Simard JM \& Watt DD (1990) Venoms and toxins. pp 414-444 in Polis GA (ed.) The Biology of Scorpions. Stanford University Press, Stanford, California

Sissom WD (1990) Systematics, biogeography and paleontology. pp 64-160 in Polis GA (ed.) The Biology of Scorpions. Stanford University Press, Stanford, California

Soleglad ME \& Sissom WD (2001) Phylogeny of the family Euscorpiidae Laurie, 1896: a major revision. pp. 25 111 in Fet V \& Selden PA (eds) Scorpions (In Memoriam Gary A. Polis, British Arachnological Society), Burnham Beeches, Bucks., UK

Stockwell S (1989) Revision of the phylogeny and higher classification of scorpions (Chelicerata). PhD Thesis, University of Berkeley, Berkeley, California. 319 pp.

Stockwell S (1992) Systematic observations on North American Scorpionida with a key and checklist of the families and genera. Journal of Medical Entomology 29: 407-422

Taib NT \& Jarrar BM (1993) Histological and histochemical characterization of the venom apparatus of the Palestine yellow scorpion, Leiurus quinquestriatus Hemprich \& Ehrenberg 1828. Tropical Zoology 6: 143152

Teruel R \& Tietz A (2008) The true identity of Rhopalurus pintoi Mello-Leitão, 1932, with notes on the status and distribution of Rhopalurus crassicauda Caporiacco, 1947 (Scorpiones: Buthidae). Euscorpius 70: 1-14

The scorpion fauna (2009) Scorpions of Oman. http://perso.orange.fr/eycb/scorpions/AIOman.htm

The scorpion files (2009) Scorpion classification. http://www.ub.ntnu.no/scorpion-files/

Torres-Larios A, Gurrola GB, Zamudio FZ \& Possani LD (2000) Hadrurin, a new antimicrobial peptide from the venom of the scorpion Hadrus aztecus. European Journal of Biochemistry 267(1): 5023-5031

Tripod (2011) Medically important species. http://members.tripod.com/c_kianwee/venom2.htm

Vachon M (1979) Arachnids of Saudi Arabia, Scorpiones. Fauna of Saudi Arabia 1: 30-66. Ciba-Geigy, Switzerland.

Van der Hammen L (1989) An introduction to comparative arachnology. SPB Academic Publishing, The Hague. 576 pp.

Van der Hammen L (1969) Notes on the mouthparts of Eukoenenia mirabilis (Grassi) (Arachnida: Palpigradida). Zoologische Mededelingen 40(3): 41-45

Van der Hammen L (1979) Comparative studies in Chelicerata I. The Cryptognomae (Ricinulei, Architarbi and Anactinotrichida). Zoologische Verhandelingen 174: 1-62

Van der Hammen L (1977a) A new classification of Chelicerata. Zoologische Mededelingen 51(20): 307-319

Van der Hammen L (1977b) The evolution of the coxa in mites and other groups of Chelicerata. Acarologia 19: $12-19$

Van der Hammen L (1982) Comparative studies in Chelicerata II. Epimerata (Palpigradi and Actinotrichida). Zoologische Verhandelingen 196: 1-78

Van der Hammen L (1985a) Comparative studies in Chelicerata III. Opilionida. Zoologische Verhandelingen 220 (30): 1-60

Van der Hammen L (1985b) Functional morphology and affinities of extant Chelicerata in evolutionary perspective. Transactions of the Royal Society of Edinburgh (Earth Sci.) 76: 137-148

Van der Hammen L (1985c) A structuralist approach in the study of evolution and classification. Zoologische Mededelingen 59(30): 391-409

Van der Hammen L (1986b) Acarological and arachnological notes. Zoologische Mededelingen 60(14): 217-230

Van der Hammen L (1986a) Comparative studies in Chelicerata IV. Apatellata, Arachnida, Scorpionida, Xiphosura. Zoologische Verhandelingen 226(28): 1-52 
Weygoldt P \& Paulus HF (1979a) Untersuchungen zur Morphologie, Taxonomie und Phylogenie der Chelicerata. 1. Morphologische Untersuchungen. Zeitschrift für zoologische Systematik und Evolutionforschung 17: 85116

Weygoldt P \& Paulus HF (1979b) Untersuchungen zur Morphologie, Taxonomie und Phylogenie der Chelicerata. 2. Cladogramme und die Entfaltung der Chelicerata. Zeitschrift für zoologische Systematik und Evolutionforschung 17: 177-200

Wheeler WC \& Hayashi CY (1998) The phylogeny of the extant chelicerate orders. Cladistics 14: 173-192

WRBU (Walter Reed Biosystematics Unit) (2011) Scorpion identification page. http://wrbu.si.edu/scorpions/ sc_phylogeny.html

Yigit N \& Benli M (2008) The venom gland of the scorpion species Euscorpius mingrelicus (Scorpiones: Euscorpiidae): morphological and ultrastructural characterization. Journal of Venomous Animals \& Toxins including Tropical Diseases 14(3): 466-480

Zamudio FZ, Gurrola GB, Arevalo C, Srreekumar R, Walker JW, Valdivia HH \& Possani LD (1997) Primary structure and synthesis of imperatoxin A (IpTxa) a peptide activator of $\mathrm{Ca}^{2+}$ release channels/ryanodine receptors. Federation of European Biochemical Societies Letters 405: 385-389

Zare Mirakabbadi A, Zolfagharian H, Hedayat A \& Jalali A (2007) Clinical and biochemical manifestations produced by scorpion (Hemiscorpius lepturus) venom in experimental animals. Journal of Venomous Animals \& Toxins including Tropical Diseases 13(4): 758-765

Zeng XC, Peng F, Luo F, Zhu SY, Liu H \& Li WX (2001) Molecular cloning and characterization of four scorpions $\mathrm{K}^{+}$channel toxins: a new subfamily of venom peptides (alpha-KTX-14) and genomic analysis of a member. Biochimie 83: 883-889

Zeng XC, Wang SX, Zhu Y, Zhu SY \& Li WX (2004) Identification and functional characterization of novel scorpion venom peptides with no disulfide bridge from Buthus martensi Karsch. Peptides 25(2): 143-150

$$
\begin{aligned}
& \text { الملخص العربى } \\
& \text { دراسة مجموعة العقارب بالمملكة العربية السعودية }
\end{aligned}
$$

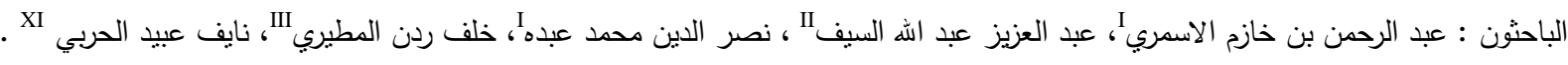

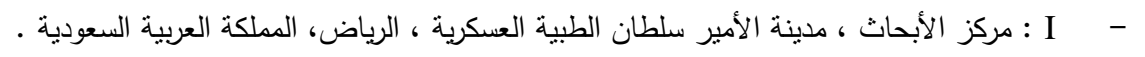

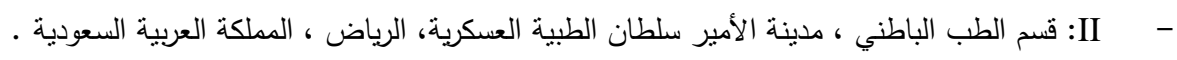

$$
\begin{aligned}
& \text { - - مسم جراحة المخ والأعصاب ، مدينة الأمير سلطان الطبية العسكرية، الرياض ، المملكة العربية السعودية. }
\end{aligned}
$$

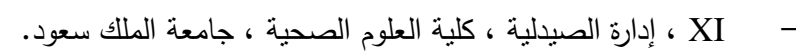

تم إجراء دراسة شاملة للعقارب بمناطق المملكة الرئيسية شملت جازان، المدينة، الباحة، حائل ، والرياض بالاضافة إلى إجراء دراسة مسحية لعدد تسعة من المحافظات بالمملكة .

أظهرت العينات البالغ عددها (1440) عينة نم جمعها من منطقة جازن وجود 10 أنواع من العقارب من فصيلة BCTHIDAE ونوعين رئيسيين

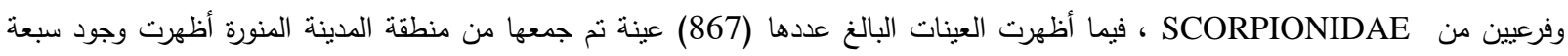
فصائل من العقارب من فصيلة BUTHIDAE ونوعين رئيسيين وفرعيين من أنواع SCORPIONIDAE ونبين بأن أحد الأنواع الفرعية من فيلة وهو عقرب الحجور (سكوربيو) SCORPIO MAURUS PLAMATUS وهاجة إلى المزيد من التأكيد على بلى وجوده من عدمه .

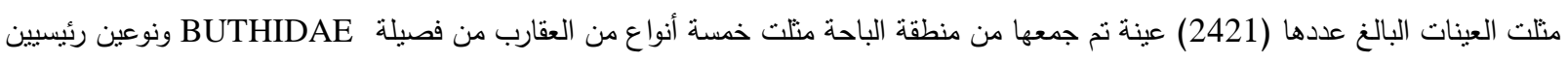
وفرعيين من SCORPIONIDAE , فيما مثلت العينات البالغ عددها (1921) والتي تم جمعها من منطقة حائل منلت ثمانية أنواع من العقارب

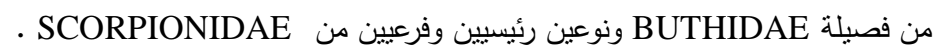

SCORPIO MAURUS KRUGLOVI كما أظهرت الدراسة إلى أن أكثر أنواع العقارب الفرعية شيوعا بهذه المنطقة هي العقرب الجزار والعقرب الحجور (سكوربيو) SCORPIO MAURUS PALMATUS (ويساورنا الثك في وجوده بهذه المنطقة) وكلا النوعين ينتميان إلى عائلة 
أثنارت الدراسة إلى أن كلا من العقارب السوداء ANDROCTONUS CRASSICAUDA والعقارب البنية LEIURUS ANDROCTONUS تنتوطن منطقتي حائل والباحة بالاضافة إلى انه نم مؤخرا نسجيل وجود العقارب نوع QUINQUESTRIATUS . بمنطقتي حائل والرياض BICOLOR

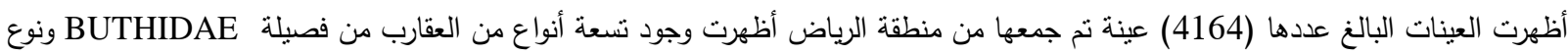

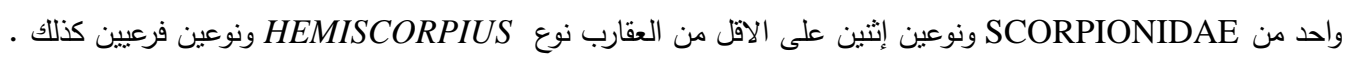

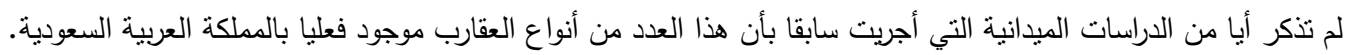

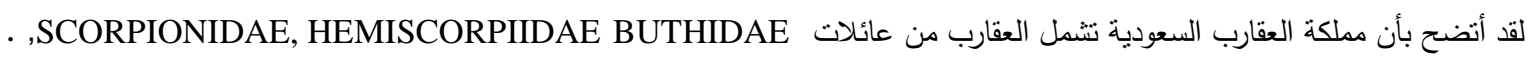
هناك على الاقل 28 نوعا رئيسيا وفرعيا من الانواع تنتمي إلى عائلات العقارب المذكورة أعلاه. ألكلمات الدليلية : الاكيل أنواع العقارب، مناطق المملكة العربية السعودية ، العقارب من فصيلة DIPLOCENTRIDAE . SCORPIONIDAE ، BUTHIDAE. 